\title{
Ricardian Model of Comparative Cost Advantage in Operating Intercity State Transport Corporation (ISTC) and Opoku-Agyemang (O.A) Travel and Tour
}

\author{
Sarah Hackman ${ }^{1 *} \quad$ Erasmus Tetteh-Bator ${ }^{2}$ Theophilus Quachie Asenso ${ }^{3}$ \\ 1. Academic Affairs, University of Health and Allied Sciences, Sokode-Lokoe, Ho, Ghana \\ 2. College of Science, Hohai University, No. 1 Xikang Road, 211100, Nanjing, China \\ 3. Department of Mathematics, Northwest University, No. 229 North Taibai Avenue, Xi'an, China
}

\begin{abstract}
This study employed the Ricardian Model of Comparative Cost Advantage, the study was able to relate to how much productive or cost efficient one transport corporation is than the other. In this case, the research centered on how much one transport provider is efficient in a particular service than the other and therefore can tell which transport corporation should resort to specializing in human transport and leave parcel transport service and vice versa due to high patronage. Stratified sampling was used to divide the population into homogeneous subgroups (Bosco training Collage, UDS Navrongo Campus, OA bus terminal and ISTC bus terminal). Structured questionnaire was design and administered to generate precise and accurate information on the effectiveness of Intercity State Transport Coaches ltd (ISTC) and Opoku Agyeman travel and tour (O.A) in terms of human transport and parceling services. The study revealed that O.A, is a private enterprise that is time conscious in terms of delivery. ISTC on the other hand specializes in safety. From the research, the cost of transporting humans from Bolgatanga to Kumasi and vice versa was lower for O.A than ISTC and this allows most customers to prefer O.A to ISTC. However, the affordability of charges of parcels moving from Kumasi to Bolgatanga and vice versa is better in ISTC than O.A. This gives O.A a comparative cost advantage in terms of human transportation than ISTC. ISTC however has a comparative cot advantage over O.A in parceling service.
\end{abstract}

Keywords: Ricardian Model, Comparative Cost Advantage, Opportunity Cost Theory, Productive Possibility Frontier, Transportation.

DOI: $10.7176 / \mathrm{JESD} / 11-4-03$

Publication date: February $29^{\text {th }} 2020$

\section{Introduction}

Transportation is the movement of people, cattle, animals and goods from one location to another. It is inevitable in the life of people and goods that are moving from one place to the other. Transportation is an important parameter in civilization since it enables trade between two parties. It is done either by foot, road, air or sea. (Bellis, M. (2012).

Humans' first means of transport were walking and swimming. The domestication of animals introduces a new way to lay the burden of transport on more powerful creatures, allowing heavier loads to be hauled, or humans to ride the animals for higher speed and duration. Inventions such as the wheel and sled helped make animal transport more efficient through the introduction of vehicles. Also, water transport, including rowed and sailed vessels, dates back to time immemorial, and was the only efficient way to transport large quantities or over large distances prior to the industrial revolution. (Bellis, M. (2012).

A mode of transport is a solution that makes use of a particular type of vehicle, infrastructure and operation. The transport of a person or of cargo may involve one mode or several modes, with the latter case being called intermodal or multimodal transport. Each mode has its advantages and disadvantages, and will be chosen for a trip on the basis of cost, capability, route, and speed. Such of these modes include land, water, rail and air. A road is an identifiable route, way or path between two or more places. Roads are typically smoothed, paved, or otherwise prepared to allow easy travel. It is the cheapest form of transportation. In the third world, about $90 \%$ of transportation is done by this mode. There are various forms of road transport including; Human-powered road transport, Animal-powered road transport, Railroad transport, Automobile road transport. (Transportation, 2016).

Transportation has a key influence on the society. Its impact cuts across the economy, planning and the environment at large. In terms of economics, transport is a key component of growth and globalization. It is a key necessity for specialization; allowing the production and consumption of products to occur at different locations. Transport allows more trade and a greater spread of people. Increasing capacity and rationality of transport has been the backbone of economic growth. Transport planning allows for high utilization and less impact regarding new infrastructure. Using models of transport forecasting, planners are able to predict future transport patterns. On the operative level, logistics allows owners of cargo to plan transport as part of the supply chain. (Transportation, 2016).

Transportation in Ghana is not different from most countries in the world. It includes all the modes of transport; 
ranging from air, through land to water. Shuttles or carriers such as aeroplanes, trains, automobiles, bicycles, boats and ships are frequently used. The most common mode of transportation patronized by Ghanaians is the road transport due to its cost-effectiveness and averagely its safety. Road transportation serves as a dominant mode of transport in Ghana, accounting for about $98 \%$ of freight and $95 \%$ of passenger movement. According to (Driver Vehicle and License Authority (DVLA), 2006), the total road transport registered between 1995 to March 2006 was 783,531. This figure consisted of 336,740 Private Cars (42\%), 100,183 Taxis (13\%), 51,724 Light Duty Vehicles (7\%), 109,258 Buses (14\%), 69,274 Heavy Duty Vehicles (9\%) and 116,352 Motor Cycles (15\%). In the field of road transport, there exist three major ways; Taxis, Trotro and Commuter buses. (Ghana Ministry of Transport Report, 2012).

All public road transport service providers are expected to register with the Ghana Private Road Transport Users (G.P.R.T.U) of the Trade Union Congress (T.U.C). For the purpose of this research, attention was shifted to intercity road transport service providers. Currently in this country, there a number of intercity road transport service providers. Among these are: VIP Transport Service, Action Transport, Opoku-Agyemang (O. A) Travel and Tour, Metro Mass Transit (MMT) and the State Transport Corporation (STC). The study had considered transportation services of Opoku-Agyemang (O.A) Travel and Tour and the State Transport Corporation.

O. A. Travel \& Tour is a Ghanaian registered Company specializing in the provision of transport management services to the general public and the mining industry. Its head office is in Kumasi. Nana Opoku Agyemang who is a renowned businessman founded O.A. Travel and Tours. After its formal registration, as a transport service it was then named O.A. Travel and Tours. Initially it was operating under the GPRTU, till it started on its own, which has been successful over the years. O.A. has grown from strength to strength over the years with such hardworking staff. O.A. is a member of the Ghana Car Rental Association.

With regards to services, Over the years the general public has realized that O.A. offers efficient services to its customers, this has increased the public patronage. Services provided can be categorized into two forms: passenger transportation and parceling services. In view of this, management was compelled to listen to the general public requests to have an extension of its services to some towns, which O.A was not in existence there. O.A. therefore extended its transport services to the following towns and Cities to continue to offers its good and reliable transport service it has rendered successfully to the public over the years. The areas are as follows; Drobo, Sunyani, Techiman, Tamale, Cape Coast, Bolgatanga, Berekum, Obuasi, Dormaa, Accra, Techiman, Sunyani, Paga, Nkwanta, Yeji. Due to the efficient and dedicated services O. A. Travels offers, it has endeared the general public to the use of its buses. Student's organizations of most of the Tertiary Institutions in Ghana have been hiring buses to their trips, hall week celebrations and vacation travels. Students from such institutions have enjoyed the good services of O.A. Transports. Opoku-Agyemang (O.A) Travel \& Tours is also providing transport services to the mining companies in AngloGold Ashanti Limited in Obuasi and Golden Star Limited at Bogoso. (OpokuAgyemang, 2016).

Intercity State Transport Service, from its name is a government owned transport service provider which offers a variety of services including passenger transport and parceling. It is one of the oldest transport operators in the country. InterCity State Transport Corporation (ISTC) has the farthest reach and widest network on the local market. With the exception of Koforidua, InterCity State Transport Corporation (ISTC) runs services to and from all Regional Capitals in Ghana. The Company has parcels service, the Package Express, and delivers packages to all destinations listed on the schedule. The Package Express targets corporate bodies, businesses and individuals that require rapid delivery of huge, medium and small parcels to destinations in and around our service stations. This includes major courier companies, pharmaceutical and chemical companies, financial institutions, security services, government ministries, departments and agencies, automobile companies, non-government organizations as well as individuals. In the aspect of parceling, ISTC employs the weight-to-cost charging system where the parcel to be delivered is charged based on its corresponding weight. (InterCity STC, 2016)

Both Opoku-Agyemang (O.A) and Intercity State Transport Corporation (ISTC) provides parcel transportation service as well as human transport service. However, it seems that the patronage of OpokuAgyemang (O.A) in terms of transporting humans is relatively higher than in InterCity State Transport Corporation (ISTC). Also, there is significantly low patronage of parcel service in Opoku-Agyemang (O.A) Travel and Tour as compared to the Intercity State Transport Corporation (ISTC). In this research, the study was interested in finding the cost involved in human and parcel transportation from the southern part of Ghana, Accra to Bolgatanga among the two transport corporations and compared their values using the Ricardian Model of Comparative Cost Advantage. By using the Ricardian Model of Comparative Cost Advantage, the study was able to relate to how much productive or cost efficient one transport corporation is than the other. In this case, the research centered on how much one transport provider is efficient in a particular service than the other and therefore can tell which transport corporation should resort to specializing in human transport and leave parcel transport service and vice versa due to high patronage. 


\section{Material and Methods}

\subsection{Data Collection Technique}

Stratified sampling was used to divide the population into homogeneous subgroups (Bosco training Collage, UDS Navrongo Campus, OA bus terminal and ISTC bus terminal) and then snow ball sampling was used to select respondents who have patronized services of both OA and ISTC transport corporations. Structured questionnaire was design and administered to generate precise and accurate information on the effectiveness of Intercity State Transport Coaches ltd (ISTC) and Opoku Agyeman travel and tour (O.A) in terms of human transport and parceling services. The targeted population for the study were students from some selected tertiary institutions (UDS and Bosco Training Collage) and passengers who have patronized the services of ISTC and OA in terms of both human transport and parceling service. A total sample of 105 were selected which consist of 35 sample from the University for Development Studies (Navrongo campus), 30 samples from Boscos Training Collage, 20 samples were selected from the passenger at the terminal of ISTC and 20 sample were also selected from the passenger at the terminal of OA.

\subsection{Spearman's Rank Correlation}

Spearman's Rank Correlation which is a nonparametric correlation was used to find the relationship between the services of OA and ISTC in terms of both human transport and parceling.

The formula for calculating the correlation coefficient is

$$
r_{s p}=1-6 \sum \frac{d^{2}}{n\left(n^{2}-1\right)}
$$

Where $\mathrm{d}$ is the difference in statistical rank of corresponding variables. the sample size.

\subsection{Ricardian Model}

In comparative cost, the Ricardian Model is mostly used which states that "even if one country is more efficient in the production of all goods (absolute advantage) than the other, both countries will still gain by trading with each other, as long as they have different relative efficiencies". (Ricardo, 1951)

The theory of comparative advantage refers to the ability of a person or a country to produce a particular good or service at a lower marginal and opportunity cost. Even if one country is more efficient in the production of all goods (absolute advantage) than the other, both countries will still gain by trading with each other, as long as they have different relative efficiencies. In economics, the law of comparative advantage says that "two countries (or other kinds of parties, such as individuals or firms there as) will both gain from trade if, in the absence of trade, they have different relative costs for producing the same goods".

The Ricardian Model: Assumptions and Results

The Ricardian comparative costs analysis is based upon the following assumptions:

(i) There is no intervention by the government in economic system.

(ii) Perfect competition exists both in the commodity and factor markets.

(iii) There are static conditions in the economy. It implies that factors supply, techniques of production and tastes and preferences are given and constant.

(iv) Production function is homogeneous of the first degree. It implies that output changes exactly in the same ratio in which the factor inputs are varied. In other words, production is governed by constant returns to scale.

(v) Labor is the only factor of production and the cost of producing a commodity is expressed in labor units.

(vi) Labor is perfectly mobile within the country but perfectly immobile among different countries.

(vii) Transport costs are absent so that production cost, measured in terms of labor input alone, determines the cost of producing a given commodity.

(viii) There are only two commodities to be exchanged between the two countries.

(ix) Money is non-existent and prices of different goods are measured by their real cost of production.

(x) There is full employment of resources in both the countries.

(xi) Trade between two countries takes place on the basis of barter.

Resources Constraints

Suppose:

- OA can produce $\mathrm{H}_{\mathrm{oa}}$ effective human transport and no parceling service, ISTC produces $\mathrm{P}_{\text {istc }}$ of effective parceling service with no human transport or some combination of these two.

- Similarly, ISTC can produce $\mathrm{H}_{\text {istc }}$ effective human transport and no parceling service, OA produces $\mathrm{P}_{\mathrm{oa}}$ of effective parceling service with no human transport or some combination of these two. 


\subsection{Comparative Cost Advantage}

Comparative cost advantage is a relation indicating to how much productive or cost efficient one country is than another. This can also be used internally as the relation showing how much efficient a company is in producing one item than another. The theory of comparative advantage is essentially the idea that even though one entity may be better at producing a good than a second entity, it still may be beneficial to trade with the second entity if they have lower opportunity costs. If our country can produce some set of goods at lower cost than a foreign country, and if the foreign country can produce some other set of goods at a lower cost than we can produce them, then dearly it would be best for us to trade our relatively cheaper goods for their relatively cheaper goods. In this way both countries may gain from trade".

The maximum potential gains from trade tend to be realized if you specialize in that activity which you can do at the lowest cost relative to other people's costs. In 1817, David Ricardo, one of the founding fathers for economics, focused on international trade when he generalized this idea into an economic law known as the law of comparative advantage which states that "mutually beneficial exchange is possible whenever relative production costs differ prior to trade.

This law is applicable to individuals, companies and nations at large. The main key to comparative advantage is opportunity cost. Opportunity Costs are the forgone alternative because of what you have chosen. Individuals and nations gain by producing goods at relatively low costs and exchanging their outputs for different goods produced by others at relatively low cost (Byrns, 2011).

\subsection{Explanation the Law of Comparative Advantage (LCA)}

According to the law of comparative advantage, even if one nation has an outright disadvantage with respect to the other nation in the production of both commodities, there is still a basis for mutually beneficial trade. This nation should specialize in the production and export of the commodity in which its absolute disadvantage is smaller (this is the commodity of its comparative advantage) and import the commodity in which it's absolute disadvantage in greater (this is the commodity of its comparative disadvantage).

Ricardo's Numerical Example One:

Brazil can produce coffee more easily than they can catch salmon, while Alaskans find it relatively easier to catch salmon than to grow coffee. Alaskans have a comparative advantage in salmon fishing whiles Brazilians in coffee production. The only way for them to have mutual benefits is for them to trade their weak products. The table below shows the production of coffee and salmon by Brazilians and Alaskans.

However, both parties can trade to gain whenever their opportunity costs differ. If Alaskans and Brazilians each specialize in their areas of comparative advantage, and if 1 pound of salmon trades for, say, 1 pound of coffee, then Alaskans can consume an extra 4 pounds of coffee daily while Brazilians can consume an additional 4 pounds of salmon

Table 1: Production by Alaskans and Brazilians before specialization (Byrns, 2011)

\begin{tabular}{|l|l|l|l|}
\hline Before Specialization & Hours Worked & Production & Consumption \\
\hline Alaskans & 4 & 5 pounds of salmon & 5 pounds \\
\cline { 2 - 4 } & 4 & 1 pound of coffee & 1 pound \\
\hline Brazilians & 4 & 1 pound of salmon & 1 pound \\
\cline { 2 - 4 } & 4 & 5 pounds of coffee & 5 pounds \\
\hline
\end{tabular}

Table 2: Production by Alaskans and Brazilians after specialization (Byrns, 2011)

\begin{tabular}{|c|c|c|c|}
\hline After Specialization & Hours Worked & Production & Consumption \\
\hline \multirow[t]{2}{*}{ Alaskans } & \multirow[t]{2}{*}{8} & \multirow[t]{2}{*}{10 pounds of salmon } & 5 pounds of salmon \\
\hline & & & 5 pounds of coffee \\
\hline \multirow[t]{2}{*}{ Brazilians } & \multirow[t]{2}{*}{8} & \multirow[t]{2}{*}{10 pounds of coffee } & 5 pounds of coffee \\
\hline & & & 5 pounds of coffee \\
\hline
\end{tabular}


Ricardo's Numerical Example Two:

Both United State of America and the United Kingdom are into the production of wheat and cloth. However, United State of America has an absolute advantage in the production of both items as shown in the table below.

Table 3: Wheat and Cloth production per man hours by U.S and U.K

\begin{tabular}{|l|l|l|}
\hline Country & Wheat & Cloth \\
\hline & Production per man hours & \multicolumn{2}{|l|}{} \\
\hline U.S & 6 & 4 \\
\hline U. K & 1 & 2 \\
\hline
\end{tabular}

From the table 3 above, the United Kingdom is half productive in terms of cloth but six times less productive in wheat. This gives the United Kingdom a comparative advantage in the production of cloth as compared to wheat. United States of America on the other hand is twice productive in cloth but six times productive in wheat. This makes the United States of America have a comparative advantage in the production of wheat.

\subsection{The Opportunity Cost Theory (OCT)}

According to the opportunity cost theory, the cost of a commodity is the amount of a second commodity that must be given up to release just enough resources to produce one additional unit of the first commodity. Thus, the nation with the lower opportunity cost in the production of a commodity has a comparative advantage in that commodity. From example two, United States of America has to give up 2/3 of a unit of cloth to release enough resources to produce an additional unit of wheat, then the opp. cost of wheat is $2 / 3$ of a unit of cloth, that is, $1 \mathrm{~W}=\frac{2}{3} \mathrm{C}$. If $1 \mathrm{~W}=2 \mathrm{C}$ in the United Kingdom, then the opportunity cost of wheat is lower in the United State of America. This gives the United State of America a comparative (cost) advantage over the United Kingdom in wheat production. However, if $\frac{1}{2} \mathrm{~W}=1 \mathrm{C}$ in the United Kingdom and $\frac{3}{2} \mathrm{~W}=1 \mathrm{C}$ in the United State of America, then opportunity cost of cloth production in the United Kingdom is lower than in the United State of America. This gives the United Kingdom a comparative (cost) advantage over the United State of America in terms of cloth production.

\section{Results and Discussion}

The well-structured questionnaire has been administered to a number of units selected from the population which represent the entire population. A total sample of 105 were selected which consist of 35 sample from the University for Development Studies (Navrongo campus), 30 samples from Boscos Training Collage, 20 samples were selected from the passenger at the terminal of ISTC and 20 sample were also selected from the passenger at the terminal of OA. Out of a total of 105 respondents, 70 were males and 35 were females. Respondents were taken from both the private sector and the public sector. 66 respondents were students, 36 were workers and 3 were unemployed.

Table 4 and Figure 1 presents the comparative studies on human transport between Intercity State Transport Coaches ltd (ISTC) and Opoku Agyeman travel and tour (O.A). From the table, it is clearly seen that O.A is mostly preferred by customers based on their condition of buses, affordability of charges, comfortability of passengers and time consciousness. Time consciousness is the key to O. A's passenger satisfaction. ISTC on the other hand provides quality service in terms of passenger safety, security and handling. They have good customer relations and take priority in treating emergencies. According to the data, ISTC has a strong hold in security and this is what engineers many people to patronize their human transport service.

Table 5 and Figure 2 presents the comparative studies on parcelling between Intercity State Transport Coaches ltd (ISTC) and Opoku Agyeman travel and tour (O.A). From the table, ISTC is most effective in terms of parceling service. Customer care, security of parcels, competence of drivers, affordability of charges and response to emergencies were in favour of ISTC. Only time consciousness was retained by O.A.

The study finds out if the effectiveness of human transport service is same across the two transport corporations. At 5\% significant level, 95\% confidence interval, analysis on human transport on the two corporations using the Welch two sample t-test was performed with the null hypothesis, $\mathrm{H}_{0}$ : Effectiveness of OA is the same as the effectiveness of ISTC in terms of human transport and an alternative hypothesis, $\mathrm{H}_{1}$ : Effectiveness of OA is not the same as the effectiveness of ISTC in terms of human transport. The result shows a mean estimate of OA as 347.3333 and that of ISTC as 343.3333. The results of $t=0.2156, \mathrm{df}=15.193$, $\mathrm{p}$-value $=$ 0.8321 indicated that the study failed to reject the $\mathrm{H}_{0}$ at $\alpha=0.05$ since the p-value $(0.8321)$ is greater than the $\alpha$ value. We therefore conclude that the services of OA and ISTC in terms of human transport the same.

Also, the study finds out if the effectiveness of parceling service is same across the two transport corporations. At $5 \%$ significant level, $95 \%$ confidence interval, analysis on parceling on the two corporations using the Welch 
two sample t-test was performed with the null hypothesis, $\mathrm{H}_{\mathrm{o}}$ : Effectiveness of $\mathrm{OA}$ is the same as the effectiveness of ISTC in terms of parceling and an alternative hypothesis, $\mathrm{H}_{1}$ : Effectiveness of OA is not the same as the effectiveness of ISTC in terms of parceling. The result shows a mean estimate of OA as 318.3333 and that of ISTC as 371. 5000.The results of $\mathrm{t}=-2.4382, \mathrm{df}=9.916$, $\mathrm{p}$-value $=0.03515$ indicated that the study had to reject the $\mathrm{H}_{0}$ at $\alpha=0.05$ since the $p$-value $(0.03515)$ is less than the $\alpha$-value. We therefore conclude that the services of OA and ISTC in terms of human transport not the same.

Results from table 6 shows the services of O.A and ISTC at full employment. From the table there is not much difference between O.A and ISTC transport corporation but O.A had a higher value in human transportation by a value of two (2). There is much higher difference in parcel services instead with about 22 between the corporations. Figure 3 shows the productive possibility frontier of the two-transport corporation, O.A and ISTC on human transportation and parcel services. It is obvious from the table above that OA has an absolute advantage in human transport and ISTC has an absolute advantage in parceling service. OA and ISTC in the pre-trade era tried to satisfy the human transport-parceling services requirement for the transport system. They therefore allocate half of their maximum number of one hundred and five respondents in human transport and the remaining 52.5 respondents to parceling.

Applying the Ricardian model of comparative advantage on the services of OA and ISTC transport corporation at full employment, table 7 presents the services output of 52.5 respondents before specialization. The total for human transportation between OA and ISTC was 21735 and the total for parceling service was 14490. The grand total for both transport companies in human transport and parcel service was 36225 . Table 8 presents the services output of 52.5 respondents after specialization. The total for human transportation between OA and ISTC was 21840, meaning that the total in human transportation has increased tremendously (only produced by OA) and the total for parceling service was 15645 . This has also increased exponentially (only produced by ISTC). The grand total for both transport companies in human transport and parcel service was 37485 after specialization. Figure 4 shows the productive possibility frontier of the two-transport corporation, O.A and ISTC on human transportation and parcel services after specialization.

It is obvious from the table 7,8 and figure 4 that O.A has a comparative advantage in human transport so they specialize in human transport. Similarly, ISTC has a comparative advantage in parceling service so they specialize in parceling service. In fact, both companies are better off during the period of specialization. Comparing the grand totals of before specialization (36225) and after specialization (37485).

\section{Conclusion}

The study was to attained a better understanding of comparative cost advantage in operating O.A and ISTC. The study revealed that O.A, is a private enterprise that is time conscious in terms of delivery. ISTC on the other hand specializes in safety. From the research, the cost of transporting humans from Bolgatanga to Kumasi and vice versa was lower for O.A than ISTC and this allows most customers to prefer O.A to ISTC. However, the affordability of charges of parcels moving from Kumasi to Bolgatanga and vice versa is better in ISTC than O.A. This gives O.A a comparative cost advantage in terms of human transportation than ISTC. ISTC however has a comparative cot advantage over O.A in parceling service.

Based on the findings of the research, the study recommends that O.A should specialize in human transport whiles ISTC should specialize in parceling Service to enhance productivity and efficiency in the production of services.

\section{References}

Aldrich, J (2004), The Discovery of Comparative Advantage, Journal of the History of Economic Thought, 26 (3), pp. 379-399.

Bhagwati, J (1964), The Pure Theory of International Trade: A Survey, The Economic Journal, 74 (293), pp. 184.

Chipman, J S (1965), A Survey of the Theory of International Trade: Part 2, The Neo-Classical Theory, Econometrica, 33 (4), pp. 685-760.

Felipe, J and M Vernengo (2002), Demystifying the Principles of Comparative Advantage: Implications for Developing Countries, International Journal of Political Economy, 32 (4), pp. 49-75.

Findlay, R (1987), Comparative Advantage, In: John Eatwell, Murray Milgate, Peter Newman and Robert Harry Inglis Palgrave (Eds.), The New Palgrave: A Dictionary of Economics, Volume 1: A - D, London: Macmillan, pp. 514-517.

Gomes, L (2003), The Economics and Ideology of Free Trade: A Historical Review, Cheltenham: Edward Elgar.

Haberler, G (1929), The Theory of Comparative Cost Once More, The Quarterly Journal of Economics, 43 (2), pp. 376-381.

Harrigan, J (2003), Specialization and the Volume of Trade: Do the Data Obey the Laws? In: E. Kwan Choi and James Harrigan (Eds.), Handbook of International Trade, Malden: Blackwell, pp. 85-118. 
Jones, R W (1980), Comparative and Absolute Advantage, Schweizer Zeitschrift für Volkswirtschaft und Statistik, 116 (3), pp. 235-260.

MacDonald, G M and J R Markusen (1985), A Rehabilitation of Absolute Advantage, Journal of Political Economy, 93 (2), pp. 277-297.

Mahmud, S F, A Ullah and E M Yucel (2004), Testing Marshall-Lerner Condition: A Non-Parametric Approach, Applied Economics Letters, 11 (4), pp. 231-236.

Maneschi, A (1998), Comparative Advantage in International Trade: A Historical Perspective, Cheltenham: Edward Elgar Pub.

Prasch, R E (1996), Reassessing the Theory of Comparative Advantage, Review of Political Economy, 8 (1), pp. 37-55.

Rehim K1l1,(2002), Absolute and Comparative Advantage: Ricardian Model, Department of Economics, Marshall Hall, Michigan State University, East Lansing, MI, 48824

Ricardo, D. (1951). Principles of Political Economy and Taxation. Cambridge: Cambridge University Press.

Ruffin, R J (2002), David Ricardo's Discovery of Comparative Advantage, History of Political Economy, 34 (4), pp. $727-748$.

Williams, J H (1929), The Theory of International Trade Reconsidered, The Economic Journal, 39 (154), pp. 195 209.

www.en.wikipedia.org/wiki/transport Transportation. (2011, November 15). Retrieved November 15, 2011, from Wikipedia: www.en.wikipedia.org/wiki/transport

\section{Appendix}

Table 4: Comparative data on human transport

\begin{tabular}{|l|c|c|}
\hline \multicolumn{1}{|c|}{ Effective Services\Transport Corporations } & OA & ISTC \\
\hline Customer Care & 364 & 385 \\
\hline Time Consciousness & 362 & 279 \\
\hline Condition of Buses & 399 & 322 \\
\hline Affordability of Charges & 311 & 294 \\
\hline Comfortability of Passengers & 390 & 368 \\
\hline Safety of Passenger & 353 & 395 \\
\hline Security of Passengers & 324 & 393 \\
\hline Response to Emergency & 305 & 317 \\
\hline Passengers Handling & 318 & 337 \\
\hline
\end{tabular}

COMPARING THE EFFECTIVENESS OF OA \& ISTC IN TERMS OF HUMAN TRANSPORT

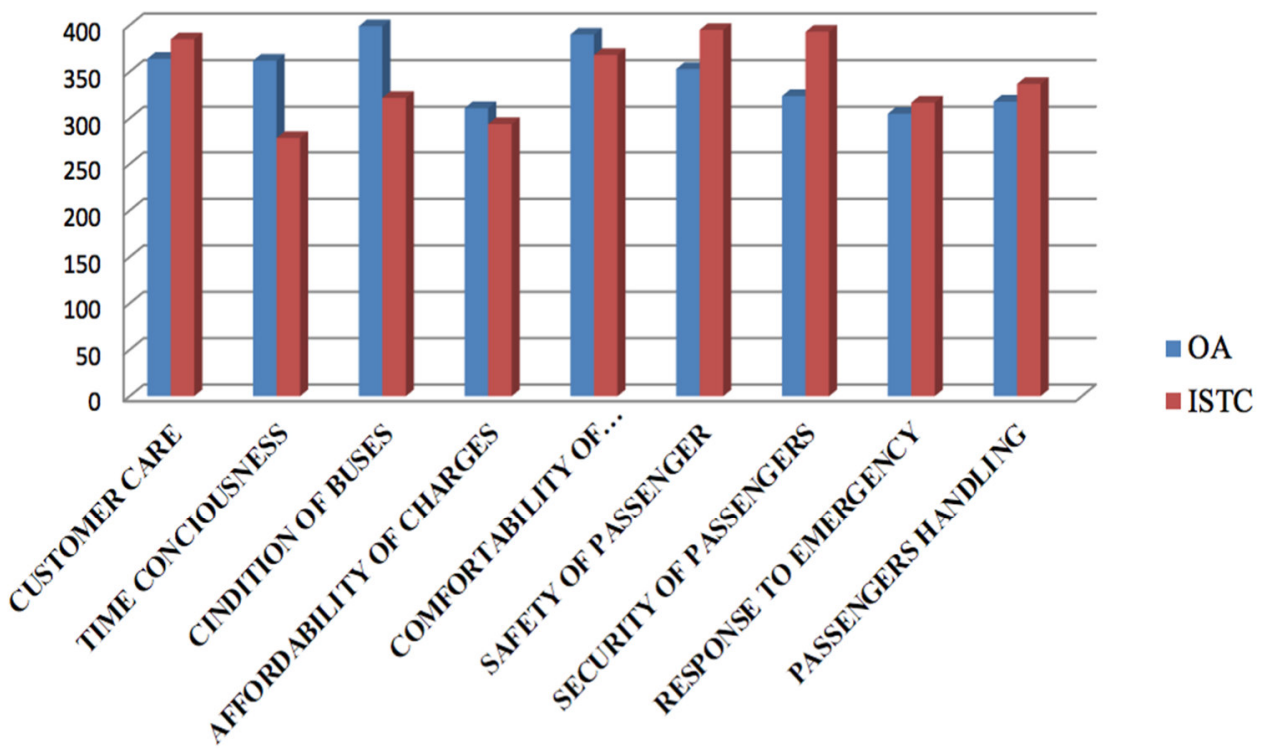

Plot Area

Figure 1: A clustered bar graph comparing the ertectiveness of O.A and ISTC in terms of human transport 
Table 5: Comparative data on parcelling

\begin{tabular}{|l|c|c|}
\hline Effective Services\Transport Corporations & OA & ISTC \\
\hline Customer Care & 343 & 399 \\
\hline Time Consciousness & 347 & 344 \\
\hline Security of Passengers & 306 & 401 \\
\hline Affordability of Charges & 273 & 335 \\
\hline Response to Emergency & 275 & 338 \\
\hline Competence of Drivers & 366 & 412 \\
\hline
\end{tabular}

\section{COMPARING THE EFFECTIVENESS OF OA \& ISTC IN TERMS PARCELING SERVICE}

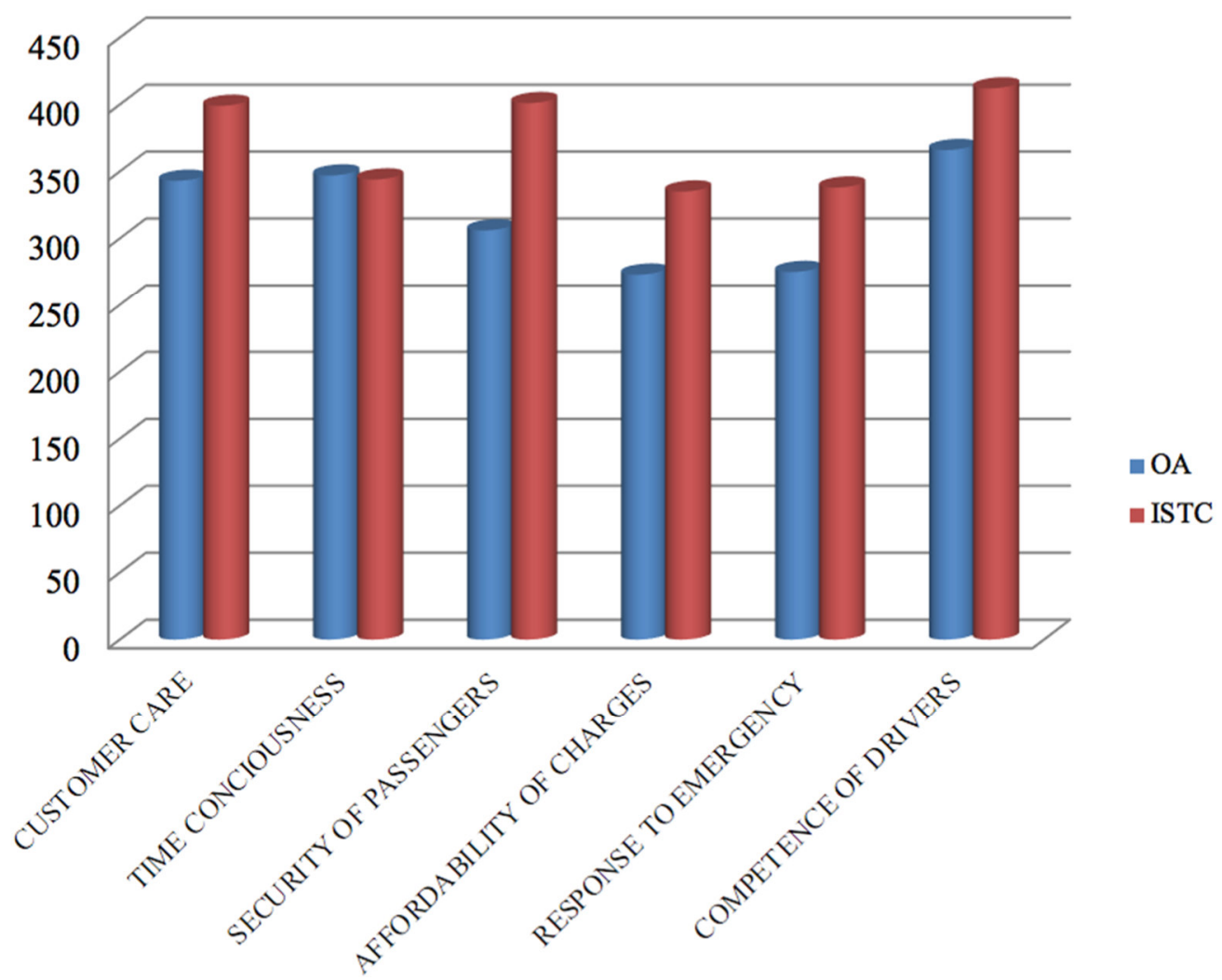

Figure 2: A clustered bar chart comparing the effectiveness of O.A and ISTC in terms of parcelling service 
Table 6 SERVICES OF O.A AND ISTC AT FULL EMPLOYMENT

\begin{tabular}{|l|c|c|}
\hline TRANSPORT COMPANY & HUMAN TRANSPORT & PARCELING SERVICE \\
\hline OA & 208 & 127 \\
\hline ISTC & 206 & 149 \\
\hline
\end{tabular}
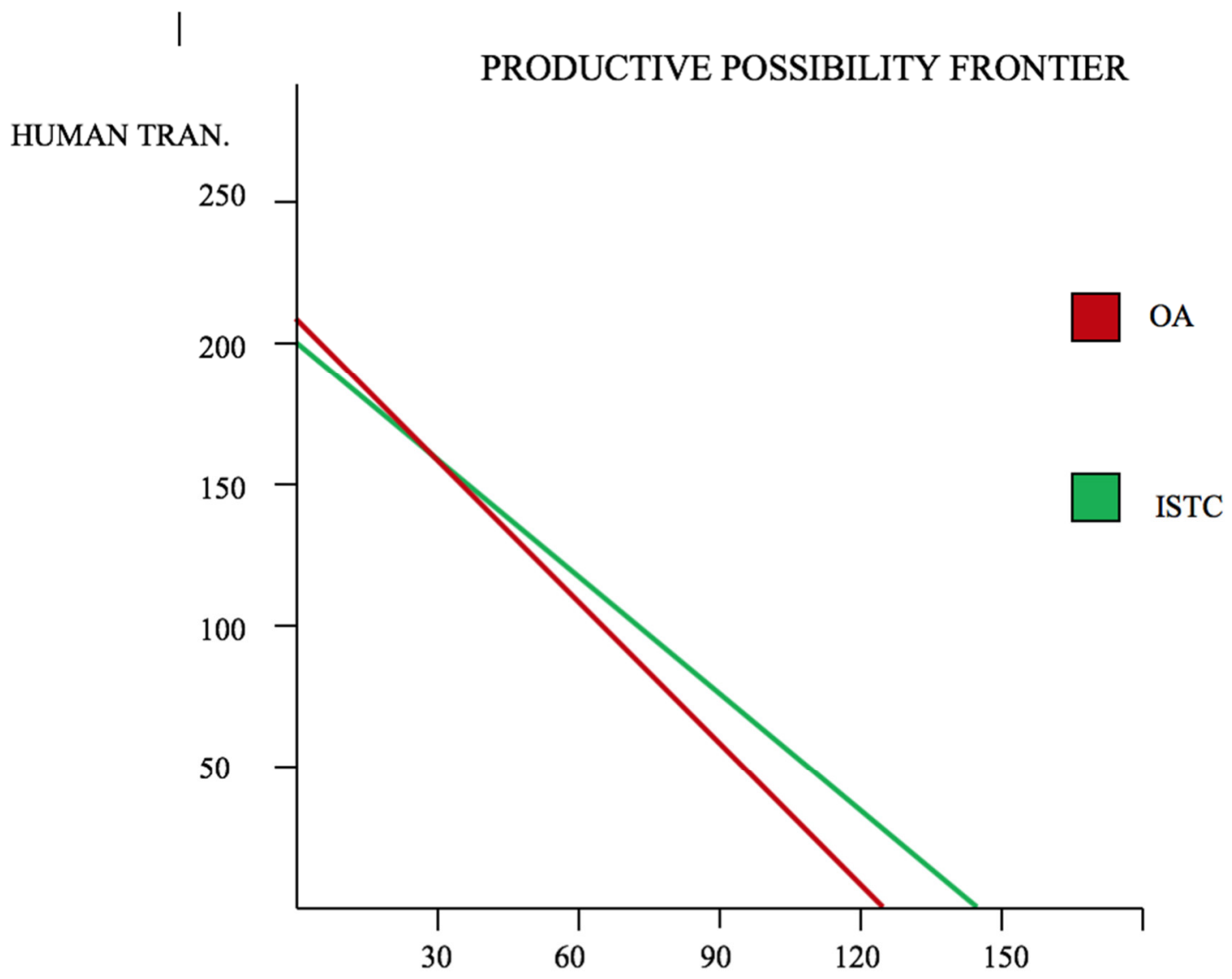

PARCELING SERVICE

Figure 3: A line showing the productive possibility frontier of O.A and ISTC 
Table 7: Services of OA and ISTC at Full Employment Before Specialization

\begin{tabular}{|l|l|l|}
\hline TRANSPORT COMPANY & HUMAN TRANSPORT & PARCELING SERVICE \\
& (output of 52.5 respondents) & (output of 52.5 respondents) \\
\hline OA & 10920 & 6667.5 \\
\hline ISTC & 10815 & 7822.5 \\
\hline Total output & 21735 & 14490 \\
\hline
\end{tabular}

Grand total is 36225

Table 8: Services of OA and ISTC at Full Employment after Specialization

\begin{tabular}{|l|l|l|}
\hline TRANSPORT COMPANY & $\begin{array}{l}\text { HUMAN TRANSPORT } \\
\text { (output of 105 respondents) }\end{array}$ & $\begin{array}{l}\text { PARCELING SERVICE } \\
\text { (output of 105 respondents) }\end{array}$ \\
\hline OA & 21840 & 0 \\
\hline ISTC & 0 & 15645 \\
\hline Total & 21840 & 15645 \\
\hline
\end{tabular}

Grand total is 37485

\section{PRODUCTIVE POSSIBILITY FRONTIER}

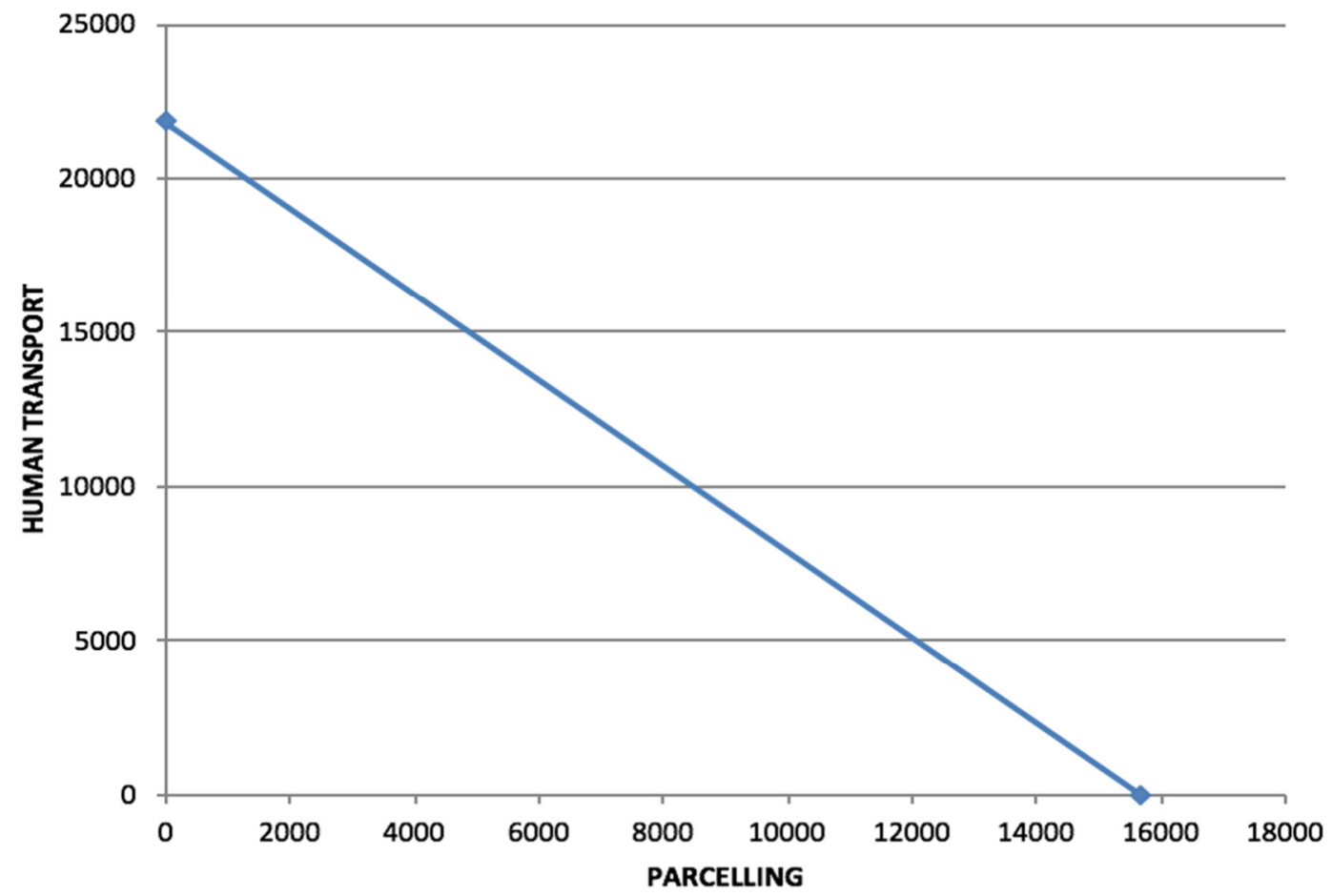

Figure 4: A line showing the productive possibility frontier of O.A and ISTC after specialization 